\title{
Application of Waterfall Model In Development of Work Training Acceptance System
}

Penerapan Model Waterfall dalam Pembangunan Sistem Penerimaan Pelatihan Kerja

Received:

20 August 2019

Revised:

17 September 2019

Accepted:

2 November 2019

\author{
$1^{*}$ Nur Hidayati, ${ }^{2}$ Sismadi \\ ${ }^{1}$ Sistem Informasi, Universitas Bina Sarana Informatika \\ ${ }^{2}$ Sistem Informasi Akuntansi, Universitas Bina Sarana Informatika \\ ${ }^{1,2}$ Jakarta, Indonesia \\ E-mail:'nur.nrh@bsi.ac.id, ${ }^{2}$ sismadi.ssm@bsi.ac.id \\ *Corresponding Author
}

\begin{abstract}
Unemployment became a social problem for the community, so they could not meet their life needs. One cause because they do not have special skills, so it is difficult to get a job. Therefore, in every local government through the UPTD Balai Tenaga Kerja, it often conducts work training for those who need it. However, the system applied in the UPTD Bogor area is still conventional. Causing problems such as data readings are less obvious; form storage and documents are not neatly arranged, so some documents are missing and lost. It resulted in a loss for the participants who would participate in job training. So it takes the development of the system to solve the problem. To improve the existing system, that is from conventional to computerized. For the development of this system, it is necessary to take steps such as those in the waterfall model. The result of the development of this system is the design of a web-based work training acceptance system that can facilitate participants to access online in the selection of the desired work exercises, and the storage of documents will be stored neatly in a database.
\end{abstract}

Keywords - Unemployment, Development, Waterfall, Web

\begin{abstract}
Abstrak-Pengangguran menjadi permasalahan sosial bagi masyarakat, sehingga mereka tidak dapat memenuhi kebutuhan hidupnya. Salah satu penyebabnya karena mereka tidak memiliki keahlian khusus, sehingga kesulitan mendapatkan pekerjaan. Oleh karena itu, di setiap Pemerintahan Daerah melalui UPTD Balai Tenaga Kerja, sering mengadakan pelatihan kerja bagi mereka yang membutuhkannya. Tetapi, sistem yang diterapkan dalam UPTD wilayah Bogor masih dilakukan secara konvensional. Sehingga menimbulkan permasalahan seperti pembacaan data kurang jelas; penyimpanan formulir beserta dokumen tidak tersusun rapi, sehingga ada beberapa dokumen yang tercecer dan hilang. Hal ini mengakibatkan kerugian bagi peserta yang akan mengikuti pelatihan kerja. Sehingga dibutuhkan adanya pembangunan sistem untuk menyelesaikan permasalahan tersebut. Dengan tujuan memperbaiki sistem yang sudah ada, yaitu dari konvensional menjadi terkomputerisasi. Supaya tujuan dari pembangunan sistem ini tercapai, maka diperlukan tahapan-tahapan yang harus dilakukan seperti yang ada dalam model waterfall. Hasil dari pembangunan sistem ini adalah rancang bangun sistem penerimaan pelatihan kerja berbasis web yang dapat memudahkan peserta untuk mengakses secara online dalam pemilihan latihan kerja yang diinginkannya dan penyimpanan dokumen akan tersimpan dengan rapi dalam suatu database.
\end{abstract}

Kata Kunci-Pengangguran, Pembangunan, Waterfall, Web 
INTENSIF, Vol.4 No.1 February 2020

ISSN: 2580-409X (Print) / 2549-6824 (Online)

DOI: https://doi.org/10.29407/intensif.v4i1.13575

\section{INTRODUCTION}

According to BPS data [1], there was an increase in the workforce from February 2017 to February 2018 by 2.39 percent, where the number of the workforce in 2017 was 127.07 million people, while in 2018, it was 133.94 million people. The number of unemployed people until February 2017 was 6.87 million people. There is a term called TPT or Open Unemployment Rate. TPT can be interpreted as an indicator that serves as a means to measure the level of labor supply that cannot be absorbed or not used by the market. TPT in February decreased from 5.33 percent in 2017 to 5.13 percent. Based on the level of education, data obtained that in February 2018, the highest TPT was at the level of vocational education, which was 8.92 percent, when compared with other levels of education. Diploma I / II / III education level is the next highest TPT, which is 7.92 percent. From these data, the level of education for SMK and Diploma I / II / III is not absorbed in the workforce. However, when compared to the conditions in February 2017, the increase in TPT occurred at the level of high school education, Diploma I / II / III, and the University, while at other levels of education decreased.

Based on the data from BPS, although there is a decrease in unemployment, this should still be a major concern. Because if unemployment is still found everywhere, it will cause social problems in the community. There are still many people who have not been able to meet their daily needs due to difficulties finding work. Or get a job, but the salary received is not much. It can be caused by the quality of the workforce, where the lower the quality of work, the smaller the chance to get the job he wants [2]. To improve the quality of workforce training is needed. Training is one of the tools that can help to match work with the expertise, skills, abilities, or skills possessed by workers or employees and as an effort to introduce certain jobs for these employees [3]. Therefore, in every local government through the UPTD Balai Labor, conduct job training for the people who need it. Labor is an important part of economic drivers in the field of human resources in a country [4].

This work training is carried out so that the community will increase their expertise so that this expertise can later be used as capital to get decent jobs. Based on the Minister of Manpower and Transmigration Regulation No. 07 of 2012, article 1 paragraph 1 that the Job Training Center (BLK) is a place for the job training process for trainees so that they are able and mastered a certain type and level of work competency to equip themselves in entering the market work and independent business or as a training ground to increase work productivity so that it can improve their welfare [5]. If the trainees can absorb their knowledge well, surely in the world of work it will produce good performance too. Performance is a result that can be 
achieved by someone in the organization following the goals desired by the organization and is done based on the responsibilities held [6].

The purpose of this study, in general, is to find out how the working procedures of the observed system and know the problems encountered in the system. While specifically, this research aims to create a new system to improve the existing system with the application program. The work training acceptance system in the UPTD Balai Labor, especially in the Bogor area, is still conducted conventionally. It causes a variety of problems, such as unclear data reading, this problem arises because when participants register for job training, participants must fill out forms first and still write the data by hand, even though we know that everyone's handwriting certainly different; storage of forms and documents from participants, which are required to take part in job training are not stored neatly, this causes the data to be often scattered and lost. Officers need a long time to find data one by one from the participants.

If this problem is not immediately sought a solution, it will be detrimental to the participant because of participants become unable to take part in the training for missing data. Problems with conventional training management are also found in research [7], which states that based on the results of the initial interview with the Head of Training and Empowerment Organization of Surakarta BBLKI regarding the implementation of participant training, there are also several problems such as starting from the process of receiving training to the implementation of the training, still done manually and not well scheduled. Research conducted at BLK Yogyakarta Bantul said that people who want to find out information about training and want to attend training must register directly with the Bantul District Vocational Training Center. Besides, the administrative division of the Bantul District Vocational Training Center is also often overwhelmed in processing the training participants' data [8].

Therefore, the UPTD Bogor Manpower Center is very much in need of development or system development. The development of the system can use the waterfall model as a helper in solving the problem. Why use the waterfall model? The waterfall model has clear stages in developing the system, which starts from the analysis, design, coding, testing, and support or maintenance. Besides that, the stages in the waterfall model must be done sequentially, so that planning in developing the system can be done clearly. The waterfall method is included in one of the SDLC (Software Development Life Cycle) models. According to D. Tegarden, A. Dennis, and B. H. Wixom in [9] said that SDLC is a process for understanding how information systems can support business needs through a series of system design processes. Besides, it is necessary to apply a web-based job training acceptance system. So that participants do not need to come directly to the UPTD to fill out forms and to complete the documents. With this webbased system, of course, it is very helpful for participants in choosing the job training they want. 
INTENSIF, Vol.4 No.1 February 2020

ISSN: 2580-409X (Print) / 2549-6824 (Online)

DOI: https://doi.org/10.29407/intensif.v4i1.13575

Participants can access it online, from registration to sending the documents. After the participant has finished registering, the participant must go through the selection process first, and if declared to pass, then the work training can be immediately carried out. Here are some of the literature conducted by previous researchers:

Research carried out by Chrisantus Tristianto in 2018 with the title Use of the Waterfall Method for the Development of a Rural Monitoring and Evaluation System. In developing the rural monitoring and evaluation system, it uses tools in the form of modeling diagrams, namely UML and implementation, and testing is carried out after the system design stage is completed [10]. Khuswatul Nur Fadhillah conducted the study, Sugeng Wahyudiono, and Sri Waluyo, in 2017 with the title Training Information Systems at the Job Training Centers in Magelang Regency. This study aims to design a training information system that can provide convenience in the training registration process, provide information on vocational training, find out how many quotas of training participants are still available, and provide information on the announcement of trainees that have been received [11].

Research conducted by I Gede Saputra Widharma in 2017 with the title Designing a Simulation System for Web-Based Course Registration with the SDLC Method. This study aims to design a simulation system for course registration for students so that it can be accessed online. Besides, the transaction data that occurs is made to be computerized. The design of this system uses the SDLC (System Development Life Cycle) method [12]. Research conducted by Diyan Agus Permana and Rizki Yudhi Dewantara in 2018 with the title Analysis and Design of Web-Based Employee Recruitment Information System (Study at PT Sumber Abadi Bersama, Gondanglegi, Malang Regency). This study aims to find out how the employee recruitment system applied at PT Sumber Abadi Bersama, which was then carried out the development of employee recruitment systems because previously, the system applied was still done manually [13].

The research was conducted by Mulyadi, Hoiriah, Deddy Supriadi, and Rina Mugiati in 2018 with the title Information System for Web-Based Course Registration at the Indonesian Music Foundation. This study aims to create a web-based course registration application. It is due; the current system still has many shortcomings. So it is necessary to build a system and to assist in the completion using the waterfall method [14]. Research conducted by Rachmat Gerhaantara and Febriliyan Samopa in 2013 with the title "Making Education and Training Information Systems in Web-Based Positions in the Employee Development Section of the Directorate General of the Treasury." This research resulted in a prototype of a web-based education and training information system that can be used to carry out the process of registration automation and the administration of training results that have been carried out [15]. 
INTENSIF, Vol.4 No.1 February 2020

ISSN: 2580-409X (Print) / 2549-6824 (Online)

DOI: https://doi.org/10.29407/intensif.v4i1.13575

Research conducted by Vindo Feladi and Chandra Lesmana in 2018 with the title "Data Processing Application at LPK (Pontianak Training Institute) Sheza Computer Pontianak." This study aims to analyze and design LPK Sheza Computer Pontianak data processing applications so that it can simplify and expedite existing activities, in this case relating to computer Kurusu conducted by course participants [16]. Research conducted by Eka Nur Ahmad Romadhoni, Triyana Widiyaningtyas, and Utomo Pujianto in 2015 with the title "Implementation of Waterfall Model in Information Systems Development Alumni SMK 1 Jenangan Ponorogo". This study aims to develop an alumni information system at SMK 1 Jenang Ponorogo webbased and use the waterfall model in its development [17]. The research was conducted by Ferdy Sibuea, Irfan Darmawan, and Warih Puspitasari in 2016 with the title "Building a WebBased Student Training Information System Using a Codeigniter Framework at the Career Development Center (CDC) of Telkom University. This research aims to build a soft-skill training information system wherein the system built some functions that can be used to overcome obstacles such as data redundancy, forget the schedule and automate the certification process [18].

Research conducted by S. Thya Safitri and Didi Supriyadi in 2015 with the title "Design of a Web-Based Job Training Information System Using the Waterfall Method." This study aims to build information systems for fieldwork practices, which were previously still done manually in some business processes so that the benefits of using technology and communication are not fully used [19].

\section{RESEARCH METHOD}

The research method is a guide for the researcher about the sequence of how to conduct research well [20]. This type of research used in the construction of this system is a qualitative study in which the data obtained comes from the results of observations, interviews, and literature studies. The data obtained will be analyzed first, then used to determine the needs needed in the development of the system. According to [21], system development or system development (system development) can mean composing a new system to replace the old system as a whole or modify an existing system. This system development is carried out due to several things, such as the existence of problems in the old system, to seize the opportunity because information technology is developing rapidly, and some orders come from the leadership or parties related to the organization. Figure 1 is the framework in this study: 
INTENSIF, Vol.4 No.1 February 2020

ISSN: 2580-409X (Print) / 2549-6824 (Online)

DOI: https://doi.org/10.29407/intensif.v4i1.13575

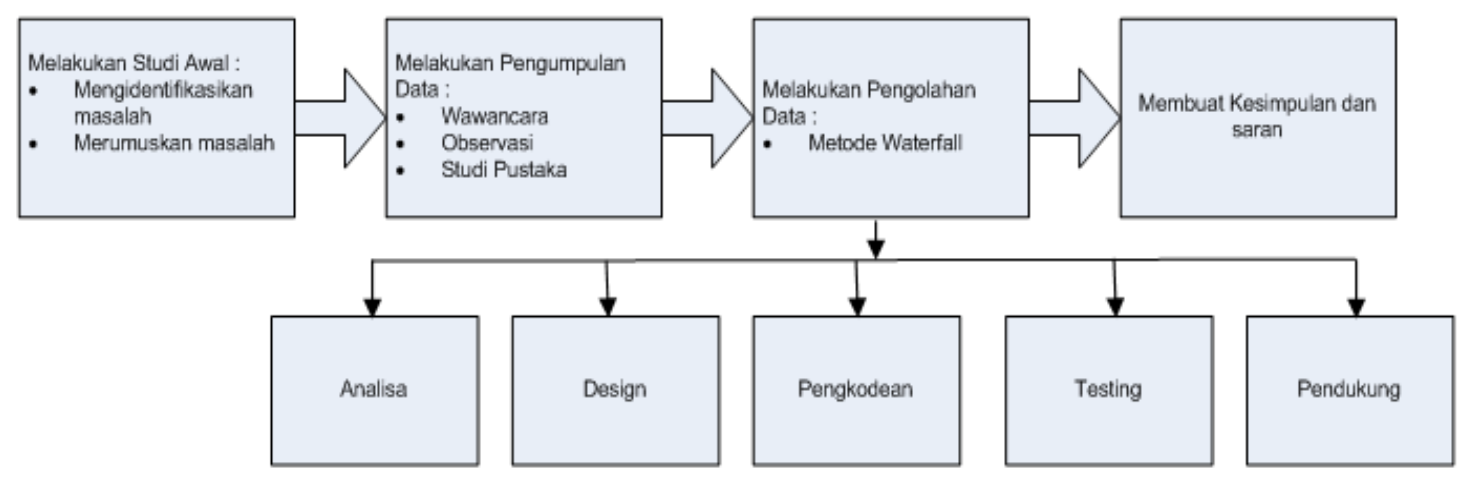

Figure 1. RESEARCH FRAMEWORK

Information:

1. Carry out initial studies

In this initial study phase, is the initial step in learning the system that runs at the UPTD Bogor Manpower Office, especially regarding the job training acceptance system. Furthermore, identifying and formulating the problems encountered in the UPTD.

\section{Perform Data Collection}

This data collection stage can be done in several ways, such as interviews, observation, and literature study. The interview is a process to obtain information from speakers by way of face to face meetings and using interview guides that have been prepared previously. Observation is an activity that makes direct observations of the object under study. While literature study means searching the literature, where the literature uses to assist in the discussion of case studies [20].

\section{Perform Data Processing}

At this stage of data processing, the writer uses the Waterfall model. The waterfall model, which is one type of the SDLC model, was chosen as the model used to help solve problems in the UPTD Balai Labor, especially in the Bogor area. According to [22], the waterfall model is also called a sequential liner, which provides software stages that can be carried out sequentially starting from the analysis phase, the design phase, the coding stage, the testing phase, and the support (maintenance) stage. UML diagrams use the system and its system development.

UML interpreted as a modeling language for software or systems that have an object-based paradigm. Modeling or modeling can later be used to make complex problems simple so that they are easy to understand and learn [23]. UML version 2.3 has 13 diagrams, which are divided into three categories, namely: structure diagrams, behavior diagrams, and interaction diagrams. However, the discussion in this journal only uses three diagrams, namely activity diagrams, use cases, and class diagrams. The three diagrams are quite representative of describing the system 
and building a job training reception system. Following is an explanation of the stages in the waterfall model:

a. Analysis

At this stage, an intensive process of gathering needs is carried out to be able to specify what the system or software needs are so that the system or software can be understood as what the user needs

b. The design

This design phase will be carried out after the analysis phase is completed. In this stage, design or design is needed to develop the system. Such as database design, interface representation, software architecture, and coding procedures. In the discussion, the database will be described in a class diagram

c. Coding

After the design phase is completed, the design is then implemented in a predetermined programming language, so that the final result of this stage is to produce an application program.

d. Testing

Testing Is the fourth step after the coding phase. The result of the coding phase is the creation of a program application. So that the application program can be directly tested using existing data in an organization. The test is carried out so that the new system when implemented, there are no obstacles or problems encountered in the system.

e. Support or Maintenance

This supporting or maintenance stage is the final stage in the waterfall method. This stage is done so that the system can be used for a long time. Maintenance of the system needs to be done on an ongoing basis, to protect the system from things that are not desirable.

Make Conclusions and Suggestions Conclusions and suggestions need to be made to know a clear picture of the condition of the existing system and the development of the system. 
INTENSIF, Vol.4 No.1 February 2020

ISSN: 2580-409X (Print) / 2549-6824 (Online)

DOI: https://doi.org/10.29407/intensif.v4i1.13575

\section{RESULT AND DISCUSSION}

The business process of the job training acceptance system at the UPTD Bogor Job Training Center can be described using the activity diagram, as Figure 2:

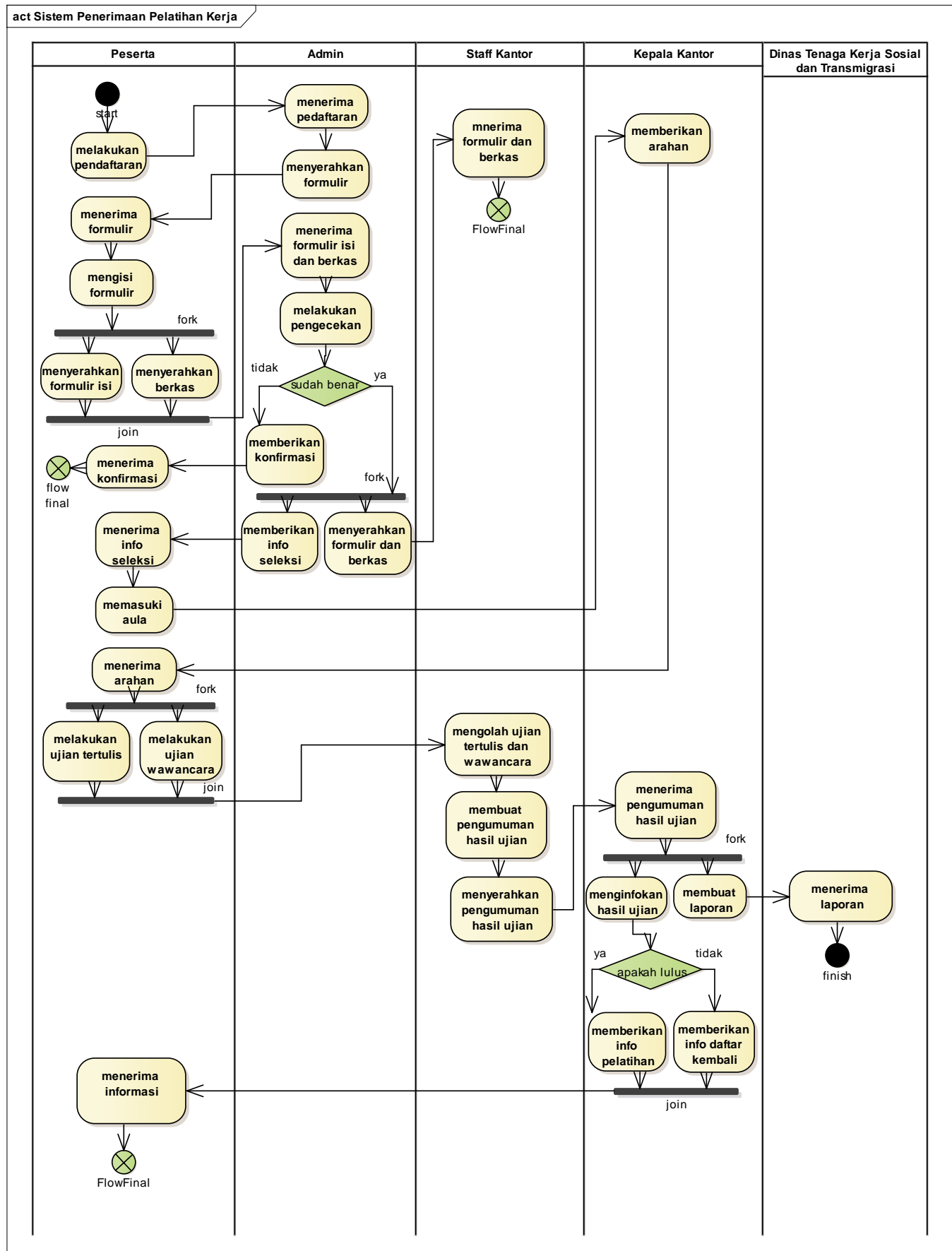

Figure 2. ACTIVITY DIAGRAM FOR RECEIVING WORK TRAINING SYSTEM

From the depiction of the current system in the Work Training Center above, the system development can be made through the Waterfall model, as follows: 
INTENSIF, Vol.4 No.1 February 2020

ISSN: 2580-409X (Print) / 2549-6824 (Online)

DOI: https://doi.org/10.29407/intensif.v4i1.13575

1. Analysis Phase

Based on the data obtained and then carried out an analysis, it can be determined regarding the analysis of needs needed in the construction of job training reception systems at the Job Training Centers, especially in Bogor. According to Pressman in Siahaan [24], requirements analysis is part of the software that needs a process that plays a role in bridging the gap that often occurs between the level of engineering needs and software design. The needs analysis can be described in a use case diagram. Figure 3 is result of the depiction using the use case:

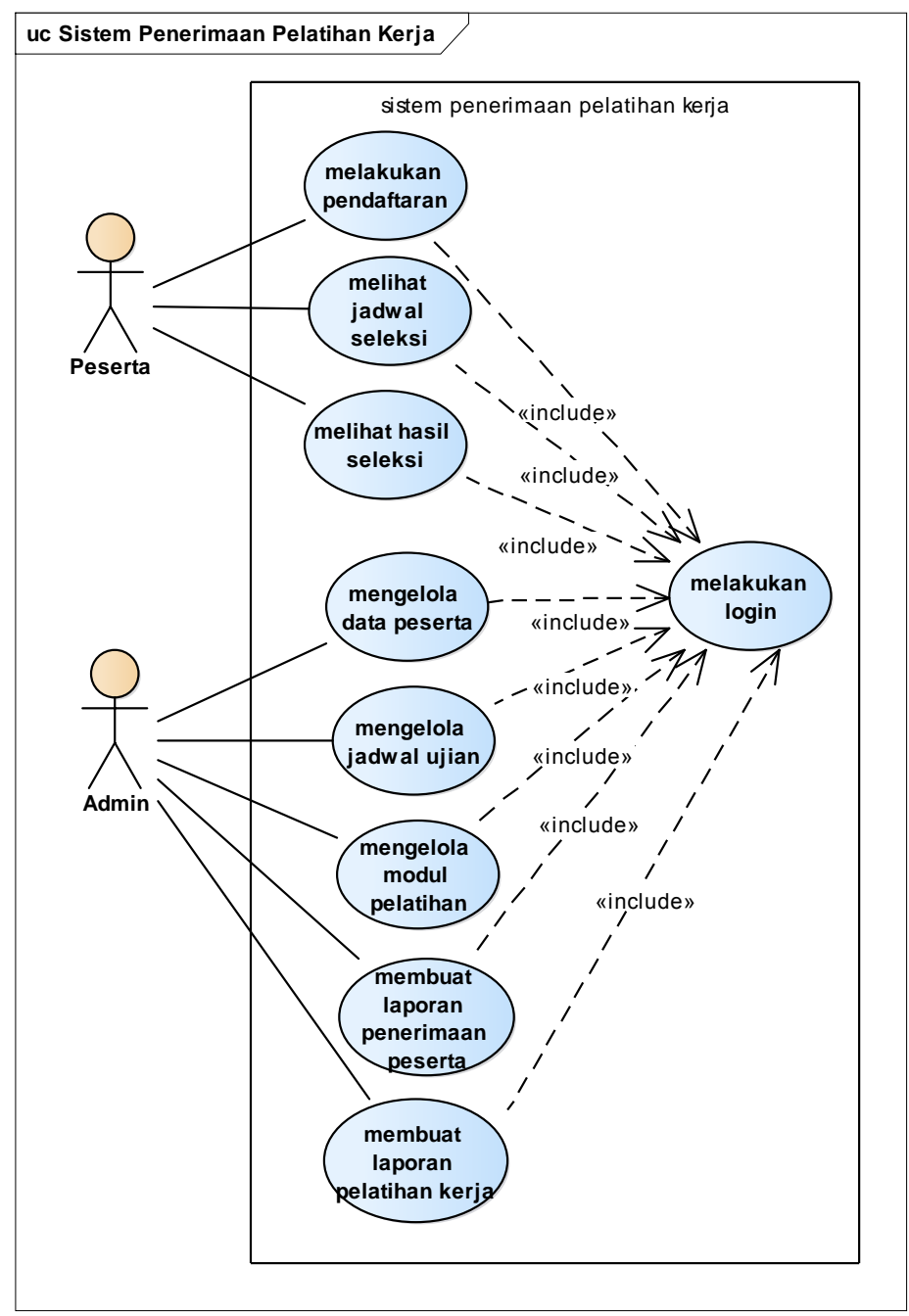

Figure 3. USE CASE DIAGRAM OF RECEPTION WORK TRAINING SYSTEM

Participants can do some data access, such as registering, can see the schedule for the selection exam that will be conducted, and can see the results of the exam. While the manager (Admin) can manage the data of participants who have registered before, can manage the schedule for the selection exam for participants, provide information on the results of the exam, do training modules used by participants during the training later and make several reports such as the acceptance report and training report work. 
INTENSIF, Vol.4 No.1 February 2020

ISSN: 2580-409X (Print) / 2549-6824 (Online)

DOI: https://doi.org/10.29407/intensif.v4i1.13575

2. The design

\section{a. Database design}

Database, in general, can be interpreted as a data storage as a substitute for conventional systems in the form of document files [25]. Depicting the database here using class diagrams. The class diagram or class diagram illustrates the structure of the system in terms of defining the classes that will be made to build the system. Classes have what are called attributes and methods or operations [26]. The description of the class diagram in the job training acceptance system at the Labor Center, especially Bogor, is as follows:

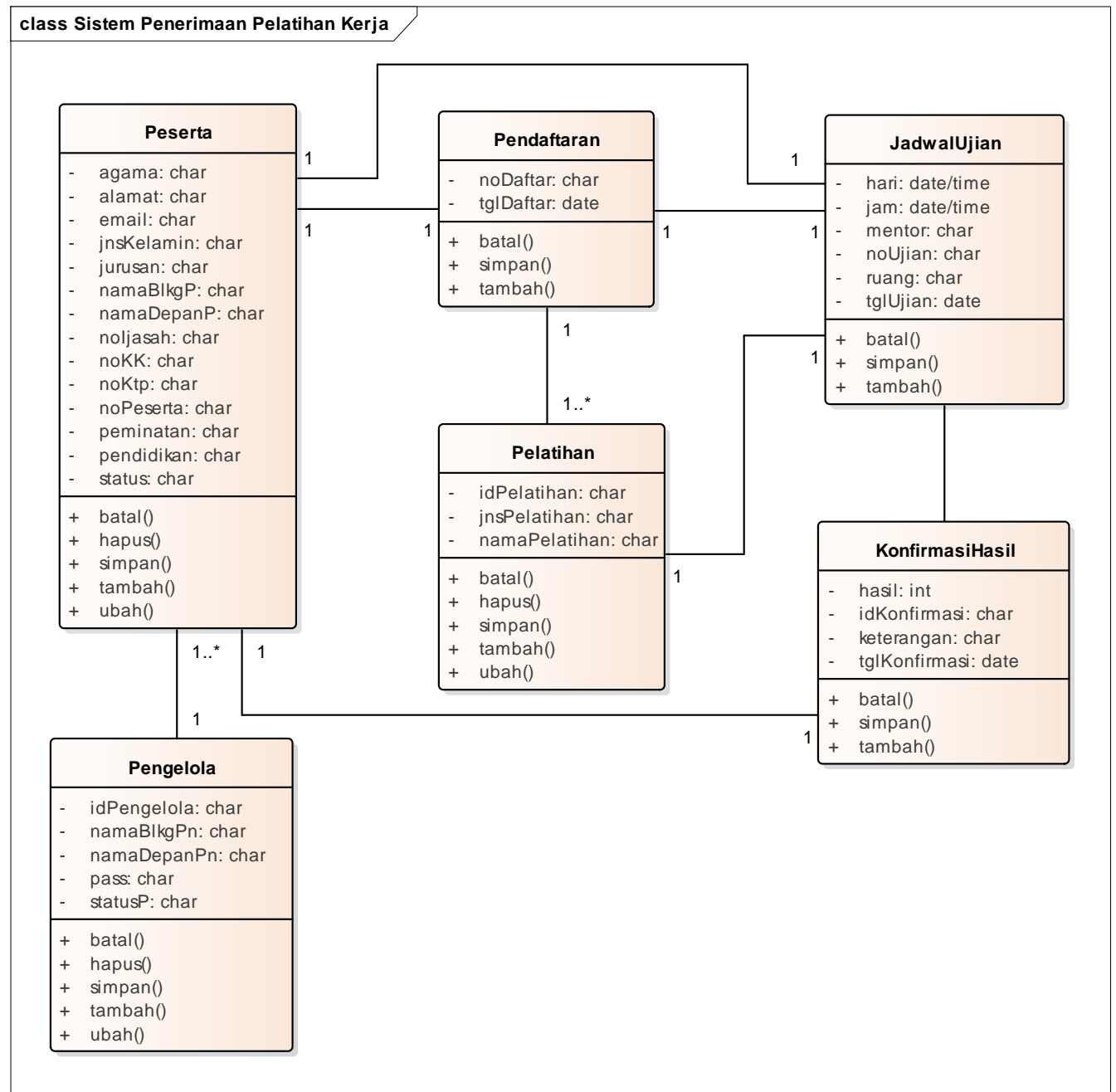

Figure 4. Class Diagram Of ACCEPTANCE SYSTEM OF WORK TRAINING

Figure 4 illustrates that each class has three main areas, namely the class name, attributes, and methods or operations. Defining a Class is the same as creating a table in a database. Classes used in the development of the system such as Participant class, Registration class, Training class, Presentation Schedule class, Confirmation Result class, and Management class. 
User Interface.

User Interface used in the construction of this job training acceptance system, as follows:

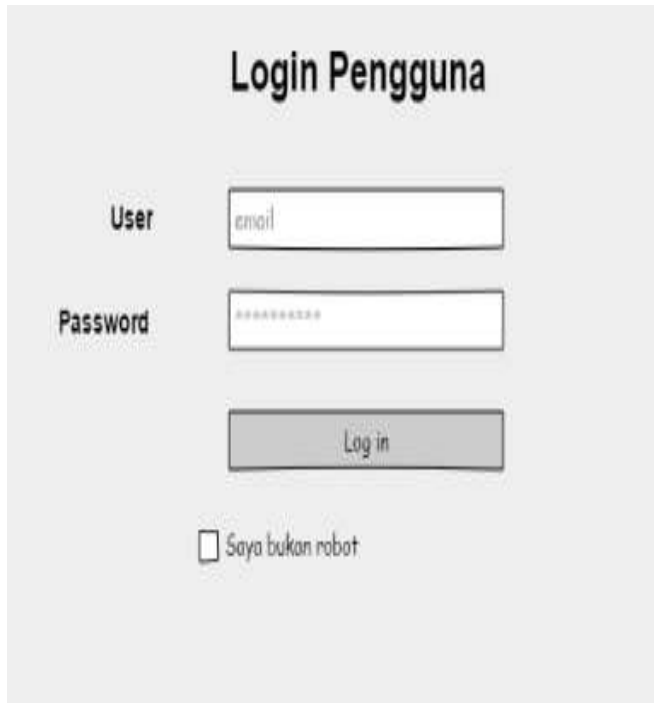

FIGURE 5. LOGIN SYSTEM

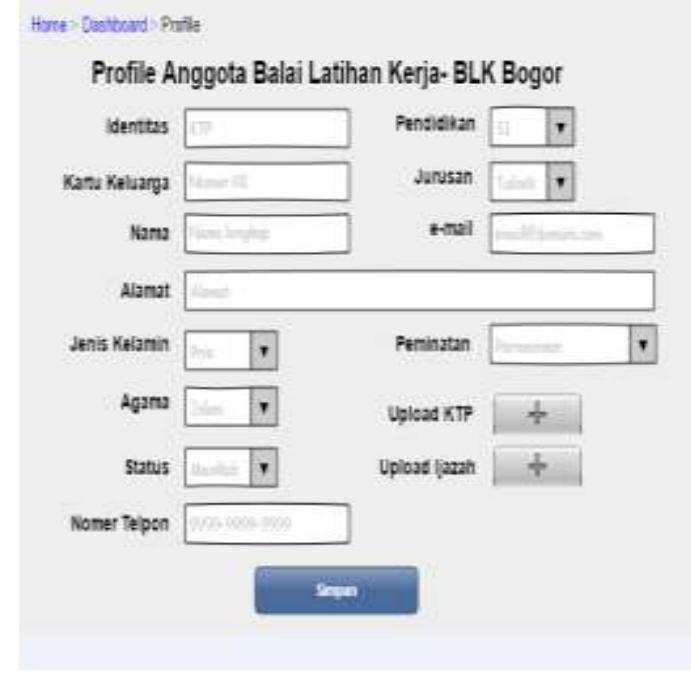

FigURE 6. PARTICIPANTS DATA

Figure 5 is Displays the Login page, which is used to enter the job training admission system. Figure 6 is Displays the Participant page, which is intended to find out the identity of the participant

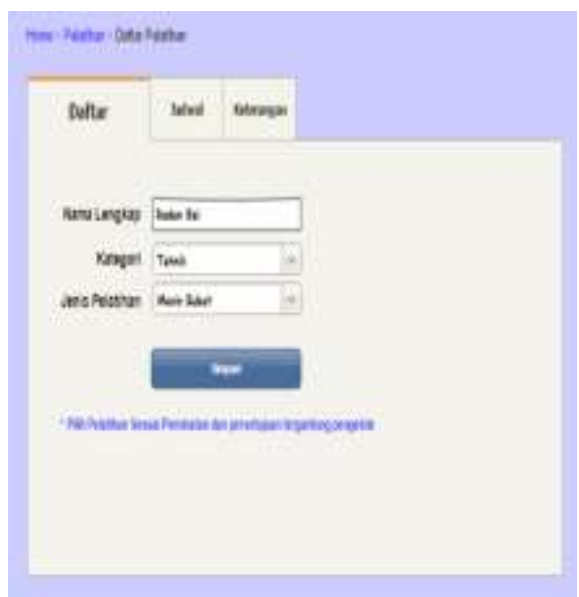

FIGURE 7. REGISTRATION

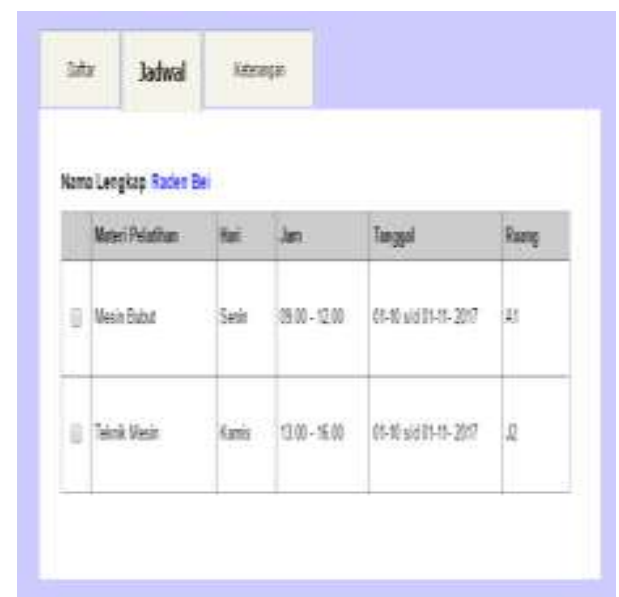

FigURE 8. SELECTION SCHEDULE

Figure 7 is Displays the Registration page, which is used by participants to register in the job training admissions system. This page can be accessed after the participant completes his identity first. Figure 8 is Display the Selection page. After participants register as participants in the job training, participants will get a schedule for Selection. 
INTENSIF, Vol.4 No.1 February 2020

ISSN: 2580-409X (Print) / 2549-6824 (Online)

DOI: https://doi.org/10.29407/intensif.v4i1.13575

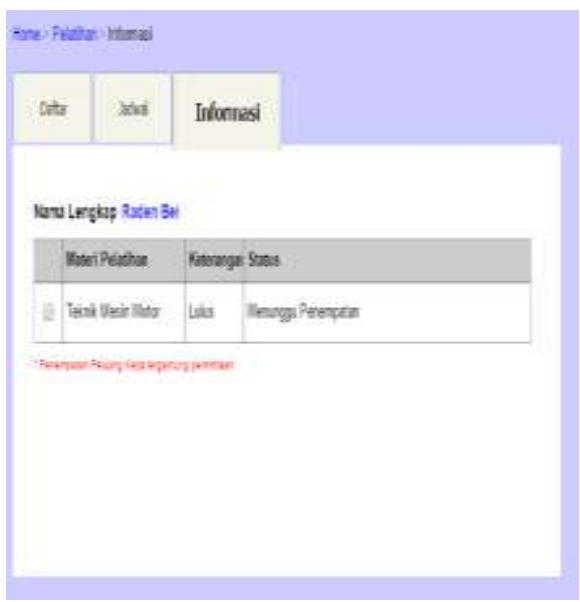

Figure 9. SELECTION RESUlts

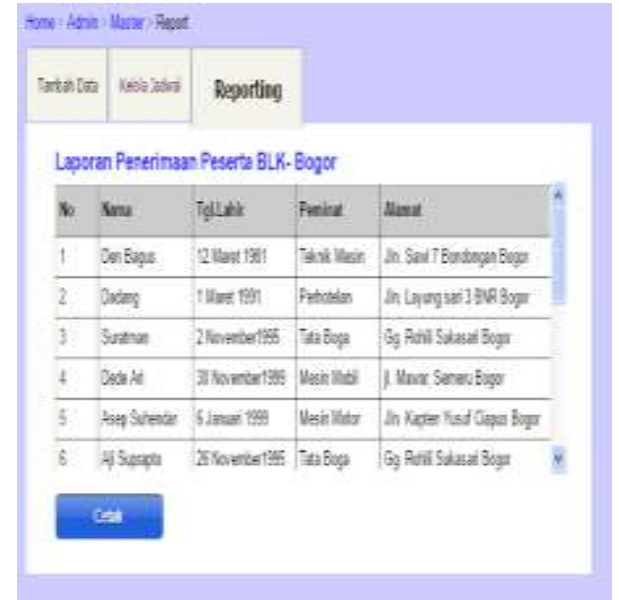

FigURE 10. ACCEPTANCE REPORT

Figure 9 is Displays the Selection Results page. After the Participants make the Selection, then to find out the results of the Selection, participants can access this page. Figure 10-11 is Displays the Job Training Acceptance Report page. This page serves to display the overall participant data in the job training acceptance system.

\section{Coding}

After the design phase is finished, the next step is to enter the coding phase. In this coding phase, the program code is written using the Netbeans programming language. As for making the database using MySQL. In making a program code, format writing must be considered, according to what is needed in the job training acceptance system. Making a program code must be unique and have meaning. The program code created is usually the primary key of each table or class.

\section{Testing}

Testing is a set of planned and systematic activities to test or evaluate the desired truth. Testing activities consist of a set or set of steps which can place the design of specific test cases and test methods. Testing is needed not only to minimize technical errors but also non-technical errors (for example testing error messages so that the user is not confused or does not understand the error message that appears or if the input and output required is very large capacity [22]. Tests carried out here use black box testing Black box testing is to test the functional specifications that have been made, without testing the design and coding of the program. Table 1 is to be able to see directly whether the functions, input and output of the software are in accordance with Required Following is an example of one of the tests in the job training acceptance information system, the authors take the example for testing Login. 
INTENSIF, Vol.4 No.1 February 2020

ISSN: 2580-409X (Print) / 2549-6824 (Online)

DOI: https://doi.org/10.29407/intensif.v4i1.13575

TABle 1. Testing The Black BoX LOGIN

\begin{tabular}{|c|c|c|c|c|c|}
\hline No. & Testing scenario & $\overline{\text { Test case }}$ & Expected Results & $\begin{array}{c}\text { Test } \\
\text { results }\end{array}$ & Conclusion \\
\hline 1. & $\begin{array}{l}\text { Username, } \\
\text { Password, and the } \\
\text { access rights are } \\
\text { not filled then } \\
\text { click the login } \\
\text { button }\end{array}$ & $\begin{array}{l}\text { Password: (empty) } \\
\text { Access rights: } \\
\text { (empty) }\end{array}$ & $\begin{array}{l}\text { The system will deny } \\
\text { access and display the } \\
\text { message "Invalid } \\
\text { password or username } \\
\text { or access rights try } \\
\text { again." }\end{array}$ & $\begin{array}{l}\text { According } \\
\text { to } \\
\text { expectatio } \\
\text { ns }\end{array}$ & Valid \\
\hline 2. & $\begin{array}{l}\text { The username is } \\
\text { filled in, the } \\
\text { password is not } \\
\text { filled in (empty), } \\
\text { and access rights } \\
\text { are not selected } \\
\text { then click the } \\
\text { login button }\end{array}$ & $\begin{array}{l}\text { Username: } \\
\text { hidayati } \\
\text { Password: (empty) } \\
\text { Access right: } \\
\text { empty) }\end{array}$ & $\begin{array}{l}\text { The system will deny } \\
\text { access and display the } \\
\text { message "Invalid } \\
\text { password or username } \\
\text { or access rights try } \\
\text { again." }\end{array}$ & $\begin{array}{l}\text { According } \\
\text { to } \\
\text { expectatio } \\
\text { ns }\end{array}$ & Valid \\
\hline 3. & $\begin{array}{l}\text { Username is not } \\
\text { filled (empty), } \\
\text { Password is } \\
\text { filled, and Access } \\
\text { Right is not } \\
\text { selected then click } \\
\text { the login button }\end{array}$ & $\begin{array}{l}\text { Access right : } \\
\text { (empty) }\end{array}$ & $\begin{array}{l}\text { The system will refuse } \\
\text { Access and display } \\
\text { messages } \\
\text { "Invalid password or } \\
\text { username or access } \\
\text { rights try again" }\end{array}$ & $\begin{array}{l}\text { According } \\
\text { to } \\
\text { expectatio } \\
\text { ns }\end{array}$ & Valid \\
\hline 4. & $\begin{array}{l}\text { Typing } \\
\text { one of the } \\
\text { conditions is } \\
\text { incorrect on the } \\
\text { Username or } \\
\text { Password, or } \\
\text { Access Right then } \\
\text { click the login } \\
\text { button }\end{array}$ & $\begin{array}{l}\text { Username: hidayati } \\
\text { (correct) } \\
\text { Password: } \\
* * * * * * \\
\text { (incorrect) } \\
\text { Access right: } \\
\text { Admin } \\
\text { (correct) }\end{array}$ & $\begin{array}{l}\text { The system will refuse } \\
\text { access and display the } \\
\text { message "Invalid } \\
\text { password or username } \\
\text { or access rights try } \\
\text { again." }\end{array}$ & $\begin{array}{l}\text { According } \\
\text { to } \\
\text { expectatio } \\
\text { ns }\end{array}$ & Valid \\
\hline 5. & $\begin{array}{l}\text { Type your } \\
\text { username, } \\
\text { password and } \\
\text { access rights with } \\
\text { the correct data } \\
\text { then click the } \\
\text { login button }\end{array}$ & $\begin{array}{l}\text { Username: hidayati } \\
\text { (benar) } \\
\text { Password: } \\
* * * * * * \\
\text { (benar) } \\
\text { Hak Akses: } \\
\text { Admin } \\
\text { (benar) }\end{array}$ & $\begin{array}{l}\text { The system will accept } \\
\text { login access and will } \\
\text { display the main page }\end{array}$ & $\begin{array}{l}\text { According } \\
\text { to } \\
\text { expectatio } \\
\text { ns }\end{array}$ & Valid \\
\hline
\end{tabular}


INTENSIF, Vol.4 No.1 February 2020

ISSN: 2580-409X (Print) / 2549-6824 (Online)

DOI: https://doi.org/10.29407/intensif.v4i1.13575

5. Support or Maintenance

At this stage, the support or maintenance of the system is implemented, especially if the system is new. Maintenance of the system needs to be done periodically and on a scheduled basis, so that it can quickly be identified shortcomings or weaknesses that exist in the system so that immediately get a solution. With this treatment, the use of the system can last a long time.

\section{CONCLUSSION}

With the construction of a job training reception system at the UPTD Balai Labor, especially in the Bogor area, it is hoped that the main objective of the development of this system is achieved; namely, the problems that exist in this system can be resolved, especially in the conventional data processing activities. This web-based system development is the right solution to solve existing problems. So that it can provide convenience and many benefits for its users. Participants will find it easier to register and submit their files because everything can be done online. So that participants do not have to come directly to the Job Training Center. The use of the waterfall method is very helpful in the process of building a job training acceptance system. This is because the stages in the waterfall method are carried out sequentially; for example, the coding stage cannot be done before the design phase is finished. Another benefit of having this new system is that the documents will be stored safely. Because it already uses a database in its data storage. With the new system, of course, requires training for office staff and administrators as direct managers of this system, so that they are accustomed to using this system and know what should be done. System maintenance is also very necessary so that the new system can be used for a long time.

\section{REFERENCE}

[1] B. P. Statistik, Keadaan Ketenagakerjaan Indonesia Februari 2018, vol. XXI, 07 Me, no. 42. Jakarta: BPS, 2018.

[2] R. J. Nur, "PELAKSANAAN TUGAS DAN FUNGSI BALAI LATIHAN KERJA SAMARINDA DALAM MENINGKATKAN KETERAMPILAN TENAGA KERJA DI SAMARINDA," Adm. negara, vol. 4, pp. 4199-4211, 2016.

[3] A. A. Sunyo, M. Al Musadieq, and M. Djudi, "PENGARUH PELATIHAN KERJA TERHADAP KINERJA KARYAWAN (Studi pada Karyawan PT. TASPEN (Persero) Cabang Malang) Arif," J. Adm. Bisnis, vol. 28, no. 1, pp. 93-99, 2015.

[4] R. D. Sari, "Pengembangan Model Pelatihan Tenaga Kerja Sektor Informal Di Dinas Tenaga Kerja Transmigrasi Dan Kependudukan Provinsi Jawa Timur," Kebijak. dan Manaj. Publik, vol. 4, pp. 107-115, 2016.

[5] Supriyono and M. Arifin, "PERANCANGAN APLIKASI PORTAL ALUMNI BALAI LATIHAN KERJA (BLK) KABUPATEN KUDUS BERBASIS WEB," J. Sist. Inf. dan Teknol., vol. 1, pp. 1-6, 2018.

[6] T. K. Puteri and H. W. Tj, "Pengaruh Pendidikan dan Pelatihan kerja serta Lingkungan 
Kerja Terhadap Kinerja Karyawan PT. Inplasco Prima Surya,” Ilm. Manaj. Bisnis, vol. 16, no. 1, 2016.

[7] A. G. Sujono and H. A. Nugroho, "Sistem Informasi Administrasi Pelatihan dengan Manajemen Workflow Berbasis Web Information System of Training Administration using Web Based Workflow Management," Pekommas, vol. 18, no. 2, pp. 83-92, 2015.

[8] Indriyanti and P. T. Rapiyanta, "Perancangan sistem informasi pendaftaran pelatihan pada balai latihan kerja bantul," in Konferensi Nasional Ilmu Sosial \& Teknologi (KNiST), 2014, pp. 295-302.

[9] R. Christopher, Hery, A. E. Widjaja, and Suryasari, "Pengembangan Aplikasi Manajemen Rekrutmen Karyawan Menggunakan Metode Profile Matching," Intensif, vol. 3, no. 1, pp. 81-92, 2019.

[10] C. Tristianto, "Penggunaan Metode Waterfall Untuk Pengembangan Sistem Monitoring Dan Evaluasi Pembangunan Pedesaan," J. Teknol. Inf. ESIT, vol. XII, no. 01, pp. 8-22, 2018.

[11] S. W. S. W. Khuswatul Nur Fadhilah, "Sistem Informasi Pelatihan Di Balai Latihan Kerja Kabupaten Magelang,” J. Transform., vol. 13, no. 2, pp. 69-75, 2017.

[12] I. G. S. Widharma, "Perancangan Simulasi Sistem Pendaftaran Kursus Berbasis Web Dengan Metode Sdlc," Matrix J. Manaj. Teknol. dan Inform., vol. 7, no. 2, p. 38, 2017.

[13] D. A. Permana and R. Y. Dewantara, "ANALISIS DAN PERANCANGAN SISTEM INFORMASI PEREKRUTAN KARYAWAN BERBASIS WEB (Studi pada PT Sumber Abadi Bersama, Gondanglegi, Kabupaten Malang)," vol. 56, no. 1, pp. 20-28, 2018.

[14] D. S. R. M. Mulyadi, Hoiriah, "Sistem Informasi Pendaftaran Kursus Berbasis Web Pada Yayasan Musik Jakarta," Ijcit, vol. 3, no. 2, 2018.

[15] R. Gerhaantara and F. Samopa, "Pembuatan Sistem Informasi Pendidikan dan Pelatihan dalam Jabatan Berbasis Web pada Bagian Pengembangan Pegawai Direktorat Jenderal Perbendaharaan," J. Tek. Pomits, vol. 2, no. 2, p. A-376-A-380, 2013.

[16] V. Feladi and C. Lesmana, "Aplikasi Pengolah Data Pada LPK (Lembaga Pelatihan Kursus) Sheza Komputer Pontianak," J. Edukasi dan Penelit. Inform., vol. 4, no. 1, p. 60, 2018.

[17] E. N. A. Romadhoni, T. Widiyaningtyas, and U. Pujianto, "Implementasi Model Waterfall Pada Pengembangan Sistem Informasi Alumni SMKN 1 Jenangan Ponorogo," Semin. Nas. Sist. Inf. Indones., no. November, pp. 445-452, 2015.

[18] F. Sibuea, I. Darmawan, and W. Puspitasari, "MEMBANGUN SISTEM INFORMASI PELATIHAN MAHASISWA BERBASIS WEB MENGGUNAKAN FRAMEWORK CODEIGNITER PADA CAREER DEVELOPMENT CENTRE (CDC) UNIVERSITAS TELKOM," in e-Proceeding of Engineering, 2016, vol. 3, pp. 3118-3127.

[19] S. T. Safitri and D. Supriyadi, "Rancang Bangun Sistem Informasi Praktek Kerja Lapangan Berbasis Web dengan Metode Waterfall," J. INFOTEL - Inform. Telekomun. Elektron., vol. 7, no. 1, p. 69, 2015.

[20] M. Nazir, Metode Penelitian. Bogor: Ghalia Indonesia, 2014.

[21] H. Tohari, Analisis serta Perancangan Sistem Informasi melalui Pendekatan UML. Yogyakarta: CV. Andi offset, 2014.

[22] A. R. Sukamto and M. Shalahuddin, Rekayasa Perangkat Lunak Terstruktur dan Berorientasi Objek. Bandung: Informatika, 2018.

[23] A. Nugroho, Pemrograman Berorientasi Objek Menggunakan C++. Yogyakarta: Andi Offset, 2017.

[24] N. Hidayati, "Implementasi Metode Rapid Application Development Dalam Pembangunan Sistem Penerimaan Kas Atas Penjualan," Paradigma, vol. XX, no. 1, pp. 39-47, 2018.

[25] S. Sucipto, "Perancangan Active Database System pada Sistem Informasi Pelayanan Harga Pasar," Intensif, vol. 1, no. 1, pp. 35-43, 2017.

[26] Y. Sugiarti, Dasar-dasar Pemrograman Java Netbeans, database, UML dan Interface. Bandung: PT. Remaja Roskadarya, 2018. 